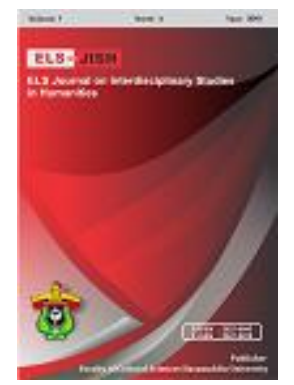

ELS-JISH

ELS Journal on Interdisciplinary Studies on Humanities

Volume 2 Issue 4, 2019

ISSN (print) : 2621-0843

ISSN (online) : 2621-0835

Homepage : http://journal.unhas.ac.id/index.php/jish

\title{
Am I a Technophile? The Narrative Study of Teachers' Belief about Digital Literacy
}

\author{
Syariful Imam Hadi Cahyono ${ }^{1}$, Nur Arifah Drajati ${ }^{2}$ Ngadiso $^{3}$ \\ 'syarifalimam@gmail.com
}

\begin{abstract}
The aim of the study is to explore teacher's belief and practice about the use of digital literacy in the EFL classroom. The framework of Borg (2006) about teacher beliefs is used as a theoretical framework for collecting and analyzing data. This study explores how teacher beliefs affect the use digital literacy. The participants of the study were two senior high school teachers in Indonesia. Researchers conducted interviews, classroom observation, and document analysis such as lesson plans, syllabi, and student assignments. The results of the study showed that it was fully crucial to provide a professional development course which was ready-to-use and met the student's and teacher's need because in-service teachers have lack of knowledge and experience about digital literacy from their formal learning context. The support of school communities in term of regulation, discussion, sharing experience, and technical aid. Moreover, promoting technology-rich environment also facilitate the use of digital literacy in the classroom in which the technology adopted should be in accordance with digital competence and the needs of students and teachers.
\end{abstract}

Keywords: Digital Literacy; EFL Teachers; Narrative Research; Teacher Beliefs

How to cite: Cahyono, S., Drajati, N., \& Ngadiso. (2019). Am I a Technophile? The Narrative Study of Teachers' Belief about Digital Literacy. ELS Journal on Interdisciplinary Studies in Humanities, 2(4), 595-606

\section{Introduction}

Teacher's belief is one of important factor that influence teachers to do or no to do something in their class to achieve the goal of teaching and learning process. Borg (2003) suggested that beliefs are a major factor which affect in various areas of education. Likewise, the decision of teachers to integrate technology into classroom is affected by belief which they hold (Galvis, 2012). Ertmer (2005) suggested that the most critical factor on how teacher used the technology was teachers' beliefs. For instance, Jääskelä, Häkkinen \& Rasku-Puttonen (2017) found that teachers who considered that activity with technology facilitate a meaningful teaching learning process had a good intention to integrate technology in the classroom. Another study by O'Neal, Gibson \& Cotten (2017) also suggested that teachers who believed that to enhance courses and engage students to promote interactive learning could be done by integrating technology.

${ }^{1}$ Universitas Sebelas Maret, Indonesia 
The integration of digital technology into the classroom is inevitable. As a response to the rapid development of digital technology and its implications for language learning and teaching in the era of information society, teachers and English language study programs at universities are expected to be able to continue to improve basic knowledge and skills related to digital literacy and how to use these skills to prepare students to be able to solve problems in a digital environment (Cote dan Miller, 2018; Sadaf \& Johnson, 2017; Dashtestani, 2014; Son et al., 2011).

Digital literacy skills are fully crucial to support students academically and professionally such as studying at school, getting better jobs, participating and interacting in the community, obtaining community services, accessing education and training at a higher level, facilitating more autonomous language learning, and provide access to other conveniences of life (Corbel \& Gruba, 2004; Healey et al., 2008; Spires \& Bartlett, 2012; Harris, 2015). In the 21 century, digital interaction is as common as today's interaction. Consequently, the need of digital literacy skill increasingly in demand.

Martin (2005) defines digital literacy as "the awareness, attitude and ability of individuals to appropriately use digital tools and facilities to identify, access, manage, integrate, evaluate, analyses and synthesize digital resources, construct new knowledge, create media expressions, and communicate with others". The new understanding of literacy consequently carries out a new concept of being literate in digital context.

There are several considerations which should be understood by teachers and students to be digitally literate in the current era, namely: understanding how digital media affects society, developing critical strategies for analyzing digital media, and independently and openly adopting devices or new tools for those who might facilitate the teaching-learning process (Voogt et al. 2013). Particularly for teachers, Hall et al. (2014) argued that digitally literate teachers are able to comprehend the use of appropriate technology in teaching and learning.

Moreover, in order to be digitally literate, according to Hockly (2011), ELT teachers are required to master four skills of digital literacy. They are languagebased literacies, information-based literacies, connection-based literacies, and redesign-based literacies. The four skills of digital literacy proposed by Hockly relies on the twenty-first century which includes information, media, and technology skills. In this study, the researcher intends to explore more deeply about the languagebased literacies.

The study of the teacher's beliefs in integrating digital technology/ICT/MALL/CALL was conducted by a number of researchers (see, for example, Alnajjar \& Brick, 2018; Budiman \& Ngadiso, 2018; Sadaf \& Johnson, 2017). Sadaf \& Johnson (2017) examined teacher beliefs and practices in the integration of digital literacy. They found that the integration of digital literacy was strongly influenced by training related to technology and the context in which digital technology was used.

However, research conducted by Sadaf \& Johnson (2017) discussed beliefs and practices of the integration of digital literacy in the field of education in general. Therefore, studies focused on teachers' beliefs and practices regarding the use of digital literacy in the EFL classroom still need to be explored. Accordingly, the study 
is done to explore in-service teachers' beliefs about the use of digital literacy in the EFL classrooms. The result of the study hopefully contribute to enrich the understanding of English teachers' belief about digital literacy in the EFL classroom.

\section{Method}

The research design used in this study was a narrative oral inquiry research design used to explore how in-service teacher beliefs affect the use of digital literacy in English classrooms. According to Barkhuizen et al. (2014) narrative inquiry is "storytelling and research together either by using stories as research data or by using storytelling as a tool for data analysis or presentation of findings."

Participants in this study were two experienced EFL teachers in which all participants were high school teachers in Indonesia. The two teachers in this study were Tika and Vina (pseudonyms). Both are women and their ages range from 35 45 years in which they have teaching experience of more than ten years. Moreover, both have experience in attending training on digital technology, and they often use digital technology in their classrooms.

To collect data from participants, life history interviews, observations, and document analysis are used. Life history interviews are used to explore how teacher beliefs affect the use of digital literacy in the classroom. The sample of question is that "do you join professional development course about digital literacy?" Barkhuizen et al. (2014) suggested that in narrative research, life history interviews, namely interviews about a person's life story by retelling the story by those who have a story, are often used to discover and understand long-term language learning experiences. Furthermore, to produce interview guidelines, researchers used Borg's (2003) theory of teacher beliefs and Hockly's theory (2013) about digital literacy. Furthermore, observation is used to elaborate participants' answers and to match the data obtained from interviews and from natural setting when the teacher is teaching. In addition, documentation obtained from teachers in the form of syllabi, lesson plans, and student assignments is also used as additional data to support data from interviews and observations.

In this study, the steps in conducting research are as follows. The researcher asked the participants to write an autobiography to reveal whether the participants met the appropriate criteria or not. Afterward, in-depth interviews were conducted to explore how teacher's beliefs affect the use digital literacy in the classroom. Observation is then done several times to find data from natural settings. Data obtained from observations are then matched with data obtained from interviews. Finally, documentation such as syllabus, lesson plans, and student assignments are requested to the teacher and analyzed by researchers as supporting data.

Thematic analysis was used to analyses the data obtained in the study. Barkhuizen et al. (2014) stated that thematic analysis is probably best suited to multiple case studies since it uncovers the possibility to compare the narratives in a data set, to establish shared themes, and to highlight individual differences. In general terms, it involves the repeated reading of the data, coding and categorization of data extracts, and their reorganization under thematic headings.

In this study, the recordings of the interview were reviewed carefully, and the transcripts are read and reviewed many times to analyses the data. The transcripts 
are initially read without analysis to gain a general sense of the information and overall meaning. Afterward, the researcher performs open coding by reading through data several times and creating tentative labels with a similar idea to summarize teachers' beliefs by looking for patterns, narrative threads, tensions, and themes that developed stories. The similar responses then are grouped into categories to identify relationships among open codes to match with the Borg' (2006) framework about teacher's belief and Hockly (2013) about digital literacy. Moreover, to identify subcategories that had the greatest explanatory potential, the frequencies of the codes are noted.

The data from other resources (observation, filed notes, and documentation) are also categorized into the existing themes which are made based on the result of the interview. It is also possible to make new themes based on the finding in the interview. Patterns, themes, and relationship between themes are then identified. Finally, the data were examined and grouped in accordance with the research questions.

\section{Results}

The data revealed the experiences of two EFL teachers who use digital literacy in their classrooms. Each participant told how their beliefs influenced them to use digital literacy in the classroom. It was revealed that teachers' beliefs about digital literacy were influenced by training and contextual factors.

\section{1. 'Give Me More Task': Tika's Story}

Tika passed her bachelor degree 15 years ago from English language teaching program in one of state university in Indonesia, and the technology at that time was not as advanced as that in this age. She never got any lesson regarding digital technology. However, Tika was fully digitally literate. That competence she developed possibly during her professional development course she regularly joined while she taught English to senior high senior students in Indonesia. She had been an English teacher for ten years.

\section{"Nothing because I have passed my bachelor degree since 15 years ago. The technology was still limited. No LCD and projector even."}

However, instead of giving up to the situation and knowledge she had, Tika sought other sources of knowledge regarding technology in the classroom. She attended several training to enhance their knowledge. There are several reasons why she was enthusiast of joining training course namely meeting the curriculum expectancy, meeting the competency of 21 th century and support of principal. She recognized that the demand of the curriculum is to meet the competency of 21 century in which one of the competence is how to implement the activity with an appropriate technology to enhance student's learning. Moreover, her headmaster also supported other teachers and her to join a training. The headmaster frequently informed all teachers about the available training.

Finally, Tika dared herself to attend professional development courses such as how to create e-module and how to use video for learning, and she felt that it was the rightest decision she ever made since courses "opened her mind". In workshop about how to use video for learning, she learnt where the source of video is, how to select 
an appropriate video, and when appropriately use the video in the classroom. She felt that the material given in the course was easy-to-apply, ready-to-use, and appropriate to student's need.

After joining several professional development courses, Tika felt confident of her competence, but it did not directly lead her to implement what she has learnt. She still felt anxious and afraid of being awkward and committing mistake when using digital literacy. She was afraid of technical problem which possibly occur and she did not understand how to solve it which then lead to the failure of her teaching learning process. She also thought how her students would response such as "will they like it, will they laugh at me when I make a mistake, and will it help or confuse them instead?"

Tika finally decided to use digital literacy in the classroom, and everything ran well initially. However, what she was afraid of happened. She got a technical problem. The LCD did not operate. She stuck and got confused. She only knew how to use a video for classroom not the LCD. One of her student initiated to solve the problem, but still it did not work. Tika increasingly got confuse and went panic. She even thought that she should not possibly have done it. She then asked one student to go to ICT teacher for help. She looked him run to get to ICT teacher's room. Fortunately, the ICT teacher came and helped her. He said that it was a simple technical problem, but for Tika it was a big trouble.

Since then, Tika frequently discussed with ICT teacher about the use of digital literacy when she has break time and no schedule to teach, or simultaneously when she got a technical problem. She also shared with other teachers about their experience, their technical problem they dealt with, and the material they used. However, it was not all teachers that have the same awareness about the use of digital literacy. Some of the in-service teachers still thought that using technology in the classroom is doubtful.

Her experience in using digital literacy in the classroom lead her to feel confident and easier to embed digital literacy in the classroom. The more she practiced, the more she got confident. Even more, she could feel the enthusiasm of her students like in her unique experience when she did not use technology in the class, her students asked "ma'am, don't you want to give us a task to make a video again?" She surprised to hear that.

"I felt like I was afraid. I doubted I could not do it. In fact, the students were enthusiast. They said "ma'am, don't you want to give us a task to make a video again?" I surprised. For example, discussing a text manually, they were reluctant to do such kind of task. And when I asked them to make a video, the result is better and more qualified."

Tika felt that her school environment encourage here to use technology. The school provide quipper, a mobile application for education, in which she could send the assignment for her class in that mobile application. She once could not attend into the class, and she had prepared for the assignment. She opened the application via her mobile phone, found the file, and uploaded it. She did need to come to the school to give the task or to permit. She only need to inform via application in her 
mobile phone. Her students then could access their assignment provided by her in their own account which could be access via their device.

Tika considered that she required to learn a lot of knowledge about digital literacy since the technology become more advance day by day. She required a training which provided ready-to-use material and meeting the student's need. She also hoped that principal provided in house training to enhance the digital competence of in-service teachers. By so, it was expected that the number of teachers who were aware of the use of digital literacy in the classroom increased which then there were more colleague to discuss. Finally, Tika told that the technology adapted by school should firstly considered the digital competence of teachers and students so that the technology can be used. Thus, it was better to initially conduct need analysis.

\section{2. "I Am Not An Old-School Teacher": Vina's Story}

Vina, an English teacher of state vocational school in Indonesia, took bachelor degree of English language teaching program in one state university in Indonesia. During her study, she did not get any lesson about the use of digital literacy in the classroom. Conversely, she frequently integrate digital literacy when she taught. School in which she taught support her to learn how to use digital literacy by providing in house training. Besides that, she also joined professional development courses held by other institutions. Both developed her digital competence.

In the initial experience of teaching, Vina only focused on textbooks and only read the material in front of the class. It was what she remembered about how to teach English based on her experience as an English learner. However, she realized that the era had been changed and the way to teach was possibly changed too. There were a lot of technology which could possibly facilitate teaching and learning in the classroom, and students possibly required new skills which is different from what she was obtained as a learner. Unfortunately, she did not have any idea how to start, how to select the best technology, and how to integrate it in her class. She merely believed that she had to change, and did not want to be an old-school teacher anymore.

In 2015, it was a turning point for her. She participated in a seminar conducted by Seamolec about Information Communication and Technology (ICT). She learnt a lot of materials there. She realized that it was possible to embed digital literacy by using wikis, blog, and videos into classroom. Once she wanted to implement what she got from seminar, she noticed that there was a school rule which forbade students to bring mobile phone. It possibly hindered her plan since she wanted to permit students to access Google translate, blogs, and other sources in the internet to enrich student's information. She then talked to her principal about her intention. She was happy to know that students were allowed to bring mobile phone if teachers ask them to in condition that the teachers were responsible for controlling students to stay focused on learning.

"[l ask my students] to visit tourist attractions, an interesting places in our area. [l ask] them make videos. They are also allowed to search information [about the tourism place] in the internet like in wikis, web, or blogs. Yesterday, my students made direction videos about how to get to one of the tourist 
attractions in our region. Besides explaining, they also provide subtitles on the videos they make."

She realized that the assignment she provided could not be done only in one meeting, but it was more meaningful. Accordingly, she provided a consultation time for her students in every single progress. She thought that teamwork and communication skill were built by this activity. It was only a video with good criteria that could be submitted. She thought that students' work should be appreciated, and her ways is by uploading her student's work to YouTube channel. However, she get difficulty to make and maintain the YouTube channel. Fortunately, a staff helped her to make a YouTube channel particularly for school and helped her to upload her students' video to YouTube channel. The available of Wi-Fi made the uploading easier.

In 2017, the school in which she taught provided in house training. It was about how to use Microsoft Office 365 for online learning. She was surprised that the technology was so advanced that teaching learning activity could be done in online environment. During training, she found difficulties in term of technical term and in understanding the material given. Fortunately, her colleagues was fully supportive. She could ask and discussed what she did not understand.

After training, she thought that she intended to implement what she had learnt. She invited her students to a computer laboratory since it was provided with Wi-Fi to connect to the internet and access the online classroom empowered by Microsoft 365. Initially, she told students about what she was going to do. She told technical terms and everything that students should knew since it was their first time to learn online. She asked students to fill a Google form to join the class. Once accepted, students directly joined her online classroom.
"By Microsoft 365, I can create online classroom for my own class and provide material which I am going to teach in that online class. To join my class, students should fill the Google form. It is a new experience. If students want to ask, they can chat me directly via the platform. After explaining, students did the task which I have provided beforehand."

Vina considered that she required to learn a lot about digital literacy from various trainings. Indeed, the school held in house training which was very useful for developing digital competence of teachers. It would be better if she could joined other trainings about digital literacy held by other institution. However, since she had to leave her class, she frequently did not get any permission to join.

\section{Discussion}

Beliefs are a major factor which affect various areas of education (Borg, 2003). Likewise, the decision of teachers to integrate technology into classroom is highly influenced by their belief which they hold (Galvis, 2012; Ertmer, 2005). Accordingly, the use of digital literacy in the classroom is possibly influenced by teacher's belief. The study explores how in-service teacher's beliefs influence the use of digital literacy in the EFL classroom. The findings of this study revealed that teacher's professional development, supports of the school communities and the availability of facilities and infrastructures influence the use of digital literacy in the classroom. 
Meanwhile, though teachers have lack of knowledge and experience about digital literacy from their formal learning such as bachelor degree, it do not hinder them to use digital literacy in the classroom.

From the results of this study, it is suggested that professional development courses such as seminars, workshops, and conferences influence the use of digital literacy in the classroom. Teacher trainings provide various insights for in-service teachers which then lead them to confidently use digital literacy in their classroom. For instance, after learning how to integrate video into classroom, teachers regularly use it as the material or student's assignment. It indicates that teacher training had a good impact on how teachers manage their classes and made decisions about what is required to do to improve student's abilities (Borg, 2003). Aşik et al. (2019) also revealed that after attending voluntary technology training sessions, teachers began to integrate digital literacy and the digital technology into their teaching. Hutchison and Reinking (2011) further found that teachers with professional development had less difficulty in using digital literacy in the classroom. In this case, professional development courses are considered as a facilitator of the use of digital literacy in the classroom (Nazari et al., 2019; Yang and Huang, 2018; Sadaf \& Johnson, 2017; Hervey, 2015).

Professional development courses also provide another opportunity for teachers such as experiencing the use digital literacy before applying it into classroom. Teachers feel insecure to use digital literacy in the classroom if they only understand the concept without having experience of using it beforehand. By getting professional development course, teachers get firsthand experience on how to use digital literacy in the classroom and how to handle technical errors that possibly occur in which it builds teachers' confidence to use it in the class (Ertmer \& Ottenbreit-Leftwich, 2010; Hew \& Brush, 2007; Smarkola, 2008). Thus, including the practice in professional developement course help teachers to get rid of uncomfortable feeling.

Furthermore, it is suggested that professional development courses provide inservice teachers with ready-to-use materials. Teachers seemingly use materials, tools, or media abundantly when they understand that those can help them to teach specific skill or specific topic. Moreover, the appropriateness of materials, tools, or media obtained from the course also becomes a consideration to use them or not. In line with the result, Magen-Nagar \& Firstater (2019) suggested that conformity between what is learnt in a training and what is needed lead teachers to use the knowledge in the classroom. Besides that, the technology adopted should in accordance with the need of students and teachers (Lam, 2000) and the digital competence of students and teachers.

Furthermore, supports from the school communities influence teachers in using digital literacy in the classroom. It is suggested that each school community which consist of principals, staff, other teachers, and students provided different level of support for the in-service teachers, but all of them are fully impact on the use of digital literacy. Principals provide support in term of permission, regulation, and the availability of facility. Staff provide support in term technical support such as creating YouTube and Instagram account. Other teachers provide support in term of discussing and sharing experience in using digital literacy. Moreover, students provide support in term of overcoming technical errors when digital technology is used. 
Borg (2003) revealed that colleagues, parents, and society became one of the factors that influenced teachers in teaching practice. In another study, it was found that teachers believed that the support of the principal, other teachers, and students influenced them to use digital literacy in the classroom (Yang and Huang, 2018; Sadaf \& Johnson, 2017). Yang and Huang (2018) further revealed that teachers need cooperation with other teachers, sharing teaching experiences in using technology, and incentives. In addition, personal support from school principals to teachers influences more teachers to use digital literacy in the classroom (Atsoglou \& Jimoyiannis, 2012; Smarkola, 2008; Sugar et al., 2004).

Furthermore, the availability of facilities such as computer labs and Wi-Fi positively influences in-service teachers to use digital literacy in the classroom. It makes the integration of digital literacy into classrooms easier. Facility seemingly provides more powerful impact on the use of digital literacy when it meets teacher's digital competence. For instance, in-service teachers with digital competence to use video and multimedia tend to integrate it into their teaching when they find that the facility such as Wi-Fi provided by the school supports their activity.

A technology-rich environment motivates and facilitates teachers in using digital literacy. Borg (2003) revealed that social reality, psychology and the school and classroom environment formed teachers to practice their beliefs. Previous research also revealed that access to technology and resources influences the use of technology and impacts the success of classroom practice (Sadaf \& Johnson, 2017; Garling, 2016; Choy et al., 2009; Wright \& Wilson, 2006). Meanwhile, it was found that the lack of financing, facilities, infrastructure, and digital content is one of the reasons for the lack of technology integration in teaching (Aşik et al., 2019; MagenNagar \& Firstater, 2019; O'Neal, Gibson \& Cotten, 2017; Liu et al., 2017).

\section{Conclusion}

This study discusses the beliefs of in-service English teachers in using digital literacy in the classroom. This study explores how the in-service EFL teacher's beliefs influence the use of digital literacy in the classroom. The findings of study revealed that it is fully crucial to provide a professional development course which is ready-to-use and meets the student's and teacher's need since in-service teachers have lack of knowledge and experience from their formal learning context. The support of school communities in term of regulation, discussion, sharing experience, and technical aid. Moreover, promoting technology-rich environment also facilitate the use of digital literacy in the classroom in which the technology adopted should be in accordance with digital competence and the needs of students and teachers.

Based on the findings of study, it is suggested that the government and school should provide a training which is ready-to-use and meets the student's and teacher's need. It is better to perform the need analysis initially before conducting a professional development course. Moreover, embedding digital literacy in the form of either material or teaching process is also required to provide teachers with digital competence and digital environment in which both are totally pivotal for teachers to use digital literacy. Furthermore, the support of school communities in term of regulation, discussion, sharing experience, and technical aid is also required. Besides that, the support can be in term of adopting technology in accordance with digital competence and the needs of students and teachers. 
In this study, the number of participants are limited, namely two in-service EFL teachers with experience over ten years. Therefore, further researchers possibly conduct research with a greater number of participants. Moreover, it is also suggested to examine participants with different levels of teaching experience such as pre-service teachers, novice teachers, and experience teachers to see whether teachers with different experiences and age have different beliefs about digital literacy.

\section{References}

Albion, P., \& Ertmer, P. A. (2002). Beyond the foundations: The role of vision and belief in teachers' preparation for integration of technology. TechTrends, 46(5), 34-38.

Asuman Aşık, Serhan Köse, Gonca Yangın Ekşi, Gölge Seferoğlu, Ricardo Pereira \& Malgorzata Ekiert. (2019). ICT integration in English language teacher education: insights from Turkey, Portugal and Poland. Computer Assisted Language Learning, DOI: 10.1080/09588221.2019.1588744

Atsoglou, K., \& Jimoyiannis, A. (2012). Teachers' decisions to use ICT in classroom practice: An investigation based on decomposed theory of planned behavior. International Journal of Digital Literacy and Digital Competence, 3(2), 20-37.

Barkhuizen, G., Benson, P., \& Chik, A. (2014). Narrative inquiry in language teaching and learning research. New York, NY: Routledge.

Borg, S. (2003). Teacher cognition in language teaching: a review of research on what language teachers think, know, believe and do. Language Teaching, 36, 81-109.

Calvani, A., Fini, A., Ranieri, M., \& Picci, P. (2012). Are young generations in secondary school digitally competent? A study on Italian teenagers. Computers and Education, 58, 797-807.

Corbel, C., \& Gruba, P. (2004). Teaching computer literacy, Teaching with new technology. Sydney: NCELTR.

Cote, T., \& Milliner, B. (2018). A survey of EFL teachers digital literacy: A report from a Japanese university. The Journal of Teaching English with Technology, 18(4), 71-89.

D., Wong, A., \& Gao, P. (2009). Student teachers' intentions and actions on integrating technology into their classrooms during student teaching: A Singapore study. Journal of Research on Technology in Education, 42(2), 175195.

Dashtestani, R. (2014). Computer literacy of Iranian teachers of English as a foreign language: Challenges and obstacles. International Journal of Pedagogies and Learning, 9(1), 87-100.doi:10.1080/18334105.2014.11082022

Dudeney, G., Hockly, N., \& Pegrum, M. (2013). Digital literacies. Harlow: Pearson.

Ertmer, P. A., \& Ottenbreit-Leftwich, A. T. (2010). Teacher technology change: How knowledge, beliefs, and culture intersect. Journal of Research on Technology in Education, 42(3), 255-284. 
Harris, K. (2015). Integrating digital literacy into English language instruction (Issue Brief). Washington, DC: U.S. Department of Education, Office of Career, Technical and Adult Education. Retrieved from https://lincs.ed.gov/programs/es/pro

Healey, D., Hegelheimer, V. H., Hubbard, P., loannou, S., Kessler, G., \& Ware, P. (2008). TESOL Technology Standards Framework. Alexandria, VA: TESOL.

Hervey, L. G. (2015). Between the notion and the act: Veteran teachers' TPACK and practice in 1: 1 settings. In C. Angeli \& N. Valanides (Eds.), Technological pedagogical content knowledge (pp. 165-189). New York: Springer.

Hew, K. F., \& Brush, T. (2007). Integrating technology in K-12 teaching and learning: Current knowledge gaps and recommendations for future research. Educational Technology Research and Development, 55, 223-252.

Hilton, J. T., \& Canciello, J. (2013). Tablet English: Student perceptions of an iPadbased digital literacy curriculum. International Journal of Digital Literacy and Digital Competence, 4(4), 1- 14.

Hockly, N. (2011). Digital literacies. ELT Journal, 66(1), 108112.doi:10.1093/elt/ccr077

Hsu, P.-S. (2016). Examining Current Beliefs, Practices and Barriers About Technology Integration: A Case Study. TechTrends, 60(1), 30-40.

Hutchison, A., \& Reinking, D. (2011). Teachers' perceptions of integrating information and communication technologies into literacy instruction: $A$ National Survey in the U.S. Reading Research Quarterly, 46(4), 308-329

Kagan, D. M. (1992). Implications of research on teacher belief. Educational Psychologist, 27, 65-90.

Lam, Y. (2000). Technophilia vs. Technophobia: A Preliminary Look at Why SecondLanguage Teachers Do or Do Not Use Technology in Their Classrooms. Canadian Modern Language Review, 56(3), 389420. doi:10.3138/cmlr.56.3.389

Lee, S. (2014). Digital literacy education for the development of digital literacy. International Journal of Digital Literacy and Digital Competence, 5(3), 29-43.

Liu, H., Lin, C.-H., Zhang, D., \& Zheng, B. (2017). Chinese Language Teachers' Perceptions of Technology and Instructional Use of Technology: A Path Analysis. Journal of Educational Computing Research, 56(3), 396-414.

Magen-Nagar, N., \& Firstater, E. (2019). The Obstacles to ICT Implementation in the Kindergarten Environment: Kindergarten Teachers' Beliefs. Journal of Research in Childhood Education, 1-15.

Magen-Nagar, N., \& Shamir, T. (2017). Evaluating the contribution of the national ICT plan to promote the work of teachers. Dapim, 64, 78-110. Hebrew.

Martin, A. (2005). DigEuLit-A European framework for digital literacy: A progress report. Journal of eLiteracy, 2(2), 130-136. 
Martin, B. (2018). Faculty technology beliefs and practices in teacher preparation through a TPaCK lens. Education and Information Technologies, 23(5), 17751788. doi:10.1007/s10639-017-9680-4

Naghmeh Nazari, Zohreh Nafissi, Masoomeh Estaji \& S. Susan Marandi | Shuyan Wang (Reviewing editor). (2019). Evaluating novice and experienced EFL teachers' perceived TPACK for their professional development, Cogent Education, 6:1

O'Neal, L. J., Gibson, P., \& Cotten, S. R. (2017). Elementary School Teachers' Beliefs about the Role of Technology in 21st-Century Teaching and Learning. Computers in the Schools, 34(3), 192-206.

Petko, D. (2012). Teachers' pedagogical beliefs and their use of digital media in classrooms: Sharpening the focus of the "will, skill, tool" model and integrating teachers' constructivist orientations. Computers \& Education, 58(4), 1351e1359. http://dx.doi.org/10.1016/j.compedu.2011.12.013.

R. Hall, L. Atkins, J. Fraser. (2014). Defining a self-evaluation digital literacy framework for secondary educators: the DigiLit Leicester project Research in Learning Technology, 22 (21440) (2014), 10.3402/rlt.v22.21440 Retrieved from http://www.researchinlearningtechnology.net/index.php/rlt/article/view/21440

Sadaf, A., \& Johnson, B. L. (2017). Teachers' beliefs about integrating digital literacy into classroom practice: An investigation based on the theory of planned behavior. Journal of Digital Learning in Teacher Education, 33(4), 129-137

Smarkola, C. (2008). Efficacy of a planned behaviour model: Beliefs that contribute to computer usage intentions of student teachers and experienced teachers. Computers in Human Behavior, 24(3), 1196-1215.

Son, J.-B., Robb, T., \& Charismiadji, I. (2011). Computer literacy and competency: A survey of Indonesian teachers of English as a foreign language. CALL-EJ, 12(1), 26-42.

Spires, H., \& Bartlett, M. (2012). Digital literacies and learning: Designing a path forward. Friday Institute White Paper Series. NC State University.

Sugar, W., Crawley, F., \& Fine, B. (2004). Examining teachers' decisions to adopt new technology. Educational Technology and Society, 7(4), 201-213.

Voogt, J., Knezek, G., Cox, M., Knezek, D., \& ten Brummelhuis, A. (2013). Under which conditions does ICT have a positive effect on teaching and learning? $A$ call to action. Journal of Computer Assisted learning, 29(1), 4-14.

Wright, V., \& Wilson, E. (2006). From preservice to inservice teaching: A study of technology integration. Journal of Computing in Teacher Education, 22(2), 4955.

Yang, S. C., \& Huang, Y.-F. (2008). A study of high school English teachers' behavior, concerns and beliefs in integrating information technology into English instruction. Computers in Human Behavior, 24(3), 1085-1103. 